\title{
Temperature Control of Soft Drinks on Vehicle with Portable Storage Thermoelectric Cooler
}

\author{
Basri $^{\mathrm{a}}$, Mustofa ${ }^{\mathrm{b} *}$, Daud Patabang ${ }^{\mathrm{c}}$, Yuli Asmi Rahman ${ }^{\mathrm{d}}$, Wahyu Haryadi Piarah ${ }^{\mathrm{e}}$ \\ aDepartment of Mechanical Engineering, Engineering Faculty, Tadulako University, Palu. Email: basri@untad.ac.id \\ bepartment of Mechanical Engineering, Engineering Faculty, Tadulako University, Palu. Email: mustofauntad@gmail.com \\ 'Department of Mechanical Engineering, Engineering Faculty, Tadulako University, Palu. Email: daudpatabang@gmail.com \\ dDepartment of Electrical Engineering, Engineering Faculty, Tadulako University, Palu. Email: yuliasmi.rahman81@gmail.com \\ e Department of Mechanical Engineering, Engineering Faculty, Hasanuddin University, Gowa. Email: wahyuhpiarah@unhas.ac.id
}

\begin{abstract}
This study aims to design a control system with fuzzy logic on a system of cooling the storage of soft drinks with thermoelectric coolers. This storage can be carried in a vehicle using a DC electric power from a photovoltaic solar cell mounted on the roof of the car. Under certain conditions the energy source of cigarette lighter in a car can replace the solar cells. The test results show that a temperature of $15^{\circ} \mathrm{C}$ can be reached within 30 minutes with fuzzy control, while without fuzzy control the time needed in 63 minutes, 30 minutes longer.
\end{abstract}

Keywords: Fuzzy TEC; Peltier effect; POTECO; photovoltaic-on roof; soft drinks

\section{Introduction}

The generation of thermoelectric technology (TE) has developed rapidly in the past decade because of its ability to convert thermal into electrical energy. Likewise, solar cell technology is often combined with a thermolectric either as a cooling solar cell or as a source of electrical energy in parallel with PV. Recent researches involving thermoelectric as an electric energy generator or thermoelectric with photovoltaic can be refer to [1-7].

In contrast, TE applications as coolants that utilize DC electric current sources are also intensively studied. Several related papers such as on $[8,9]$ and that combines TE as a coolant and a power plant at the same time [10]. The working principle can be seen in Fig. 1, where TE as a TEC cooler and as an electric energy generator is TEG.

The problem in the TEC application is temperature control that is in accordance with the wishes. Control systems in TEC applications are still rarely done. Therefore, this study will display temperature control schemes using fuzzy logic compared with no fuzzy programs as preservatives or soft drinks coolers on portable boxes. Temperature control is very useful that suits the needs of cooled objects. The thermoelectric phenomenon as a cooler

\footnotetext{
${ }^{*}$ Corresponding author. Tel.: +62-813-4107-4257
}

Palu, Indonesia, 94118

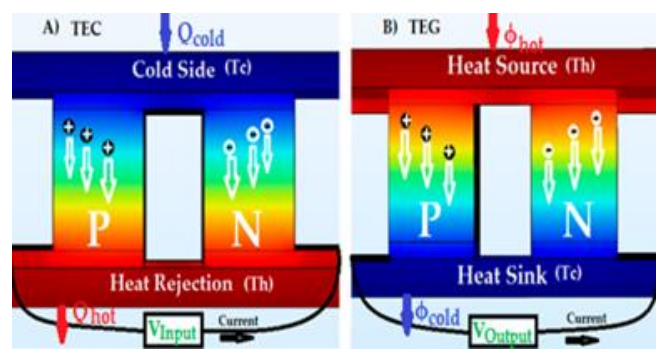

Figure 1. working principle of; (A) Thermoelectric Cooler; (B) Thermoelectric Generator [10]

is known as the Peltier effect [11]. The use of buck converter with fuzzy-PID control from DC motor energy sources has been displayed by Jumiyatun and Mustofa [12]. This control characteristic can be applied to this TEC paper research.

\section{Portable Storage of Soft Drinks on Vehicle}

The need for drivers and passengers on vehicles will treat fresh and cold drinks throughout the trip cannot be ignored. Therefore, it needs the storage cooler by utilizing the Peltier effect of the thermoelectric cooler (TEC) that utilize a DC electric current supply from photovoltaic solar cells that can be placed on the vehicle roof. Besides that, if soft drink needs are still needed until the night during the trip, the DC source can be obtained from the cigarette lighter plug on the car. The model of this cooler storage is abbreviated 


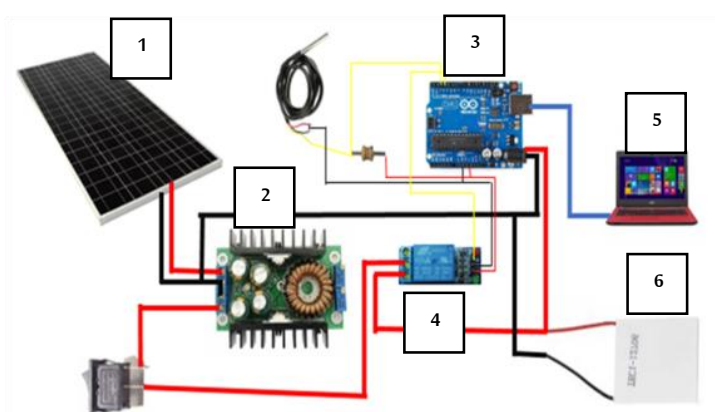

Figure 2. Experimental set-up; (1) PV; (2) Converter step-up stepdown; (3) Arduino; (4) Relay 12 V; (5) LCD; (6) TEC

POTECO (Portable Storage Thermoelectric Cooler) as explained as follows.

\section{Experimental Set-up}

The design of this test can be seen in the scheme of Fig. 2 and block diagram in Fig. 3 which places polycrystalline solar cell as DC power energy sources. From Fig. 2, PV produces voltage with an average of 19 Volt. This voltage goes to the buck boost converter with an output setting of 12 Volt. This output is the source for TEC and Arduino. Relay is connected between 12 Volt and TEC voltage output which will disconnect/connect depending on the control commands of Fuzzy Logic contained in Arduino. The LCD functions to display temperature. The polycrystalline PV solar cell is Solartech with a capacity of $85 \mathrm{Wp}$, a buck converter circuit step up-step down, a thermoelectric TEC 12706 for cooling soft drinks in the storage, a relay, and then Arduino as controller. The control method used is fuzzy logic to make the temperature constant at $15^{\circ} \mathrm{C}$.

\section{Results and Discussion}

To verify the POTECO scheme above, the cooler has been created as shown in Fig. 4(a) by placing the TEC module on the side wall of the container. Cold side of the module is inside the container of the refrigerator and hot side is in contact with the

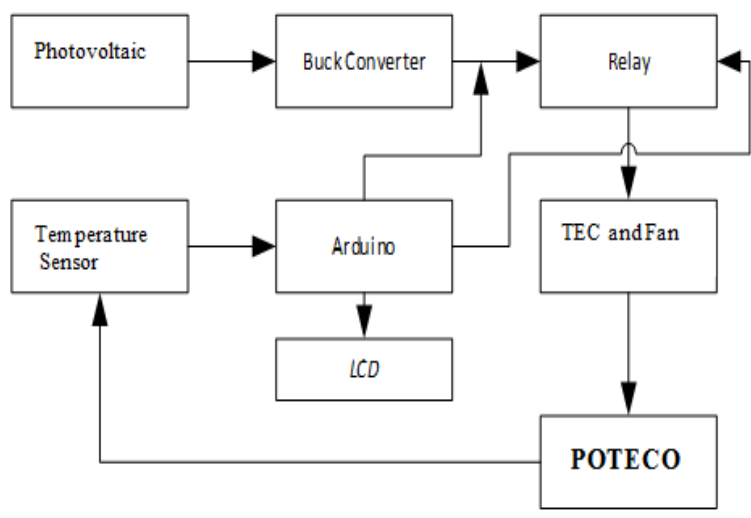

Figure 3. Block diagram of POTECO

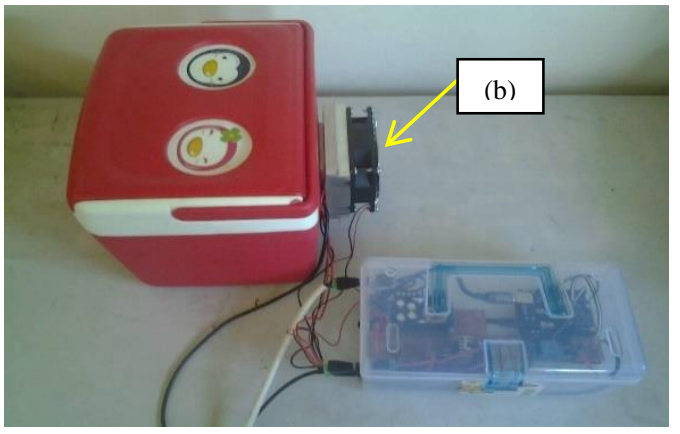

(a)

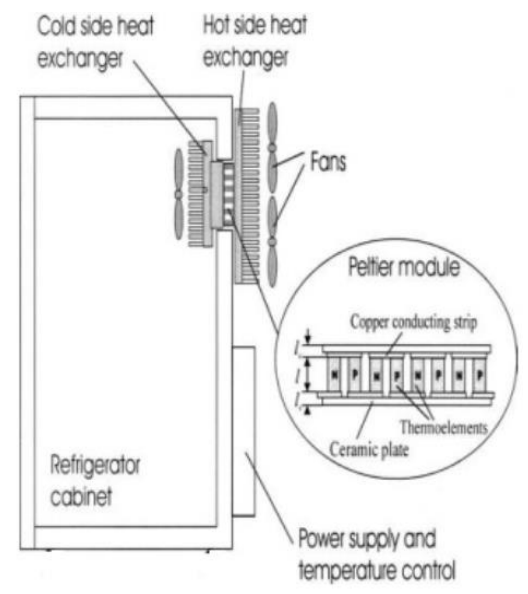

(b)

Figure 4. POTECO (a) and the TEC module detail (b) [13]

Table 1. Temperature vs Time of POTECO

\begin{tabular}{|c|c|}
\hline TEMPERATURE $\left({ }^{\circ} \mathrm{C}\right)$ & TIME (MINUTES) \\
\hline 27.44 & 0 \\
\hline 27 & 0.6 \\
\hline 26 & 0.7 \\
\hline 25 & 1.5 \\
\hline 24 & 2 \\
\hline 23 & 2.53 \\
\hline 22 & 3.2 \\
\hline 21 & 4.1 \\
\hline 20 & 5.3 \\
\hline 19 & 7.2 \\
\hline 18 & 8.4 \\
\hline 17 & 10.46 \\
\hline 16 & 16.7 \\
\hline 15 & 26.2 \\
\hline 14 & 55.1 \\
\hline 13.88 & 63.37 \\
\hline
\end{tabular}




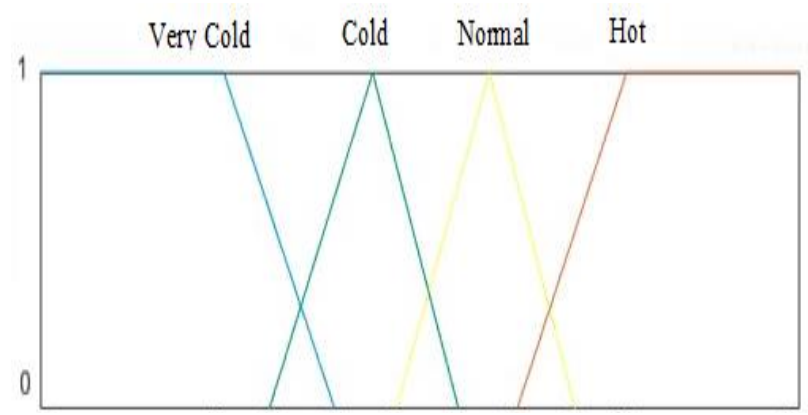

Figure 5. Fuzzy rule of POTECO

surrounding air in the vehicle cabin. Heat will be removed from hot side with help of Aluminum heat sink. Heat sink is connected on the hot side of the module. Min and Rowe [13] also put the TEC module like that as depicted in Fig. 4(b).

From the test results showed that the storage temperature reached $13.88^{\circ} \mathrm{C}$ in 63.37 minutes as the data in Table 1 . This figure was obtained without system control.

\subsection{Fuzzy controls}

Fuzzy rules are simply made as shown in Figure 5. Furthermore, this fuzzy rule can be referred to [14].

The above rule means that:

1. If temperature Very Cold ( $<=15$ ), relay OFF 30 seconds

2. If temperature Cold ( $14-17$ ), relay OFF 20 seconds

3. If temperature Normal ( $16-19)$, relay OFF 10 seconds

4. If temperature $\mathbf{H o t}(>=18)$, Then relay $\mathrm{ON}$

Or in the form of computer program:

if (temperaturenow $<=15)$ \{relay off $=30$ seconds $\}$ else if $(14<$ temperaturenow \&\& temperaturenow < $=$ 17) $\{$ relay off $=20$ seconds $\}$

else if $(16<$ temperaturenow \& \& temperaturenow < $<19)$

\{ relay off $=10$ seconds $\}$

else if $(18<=$ temperaturenow) \{relay on

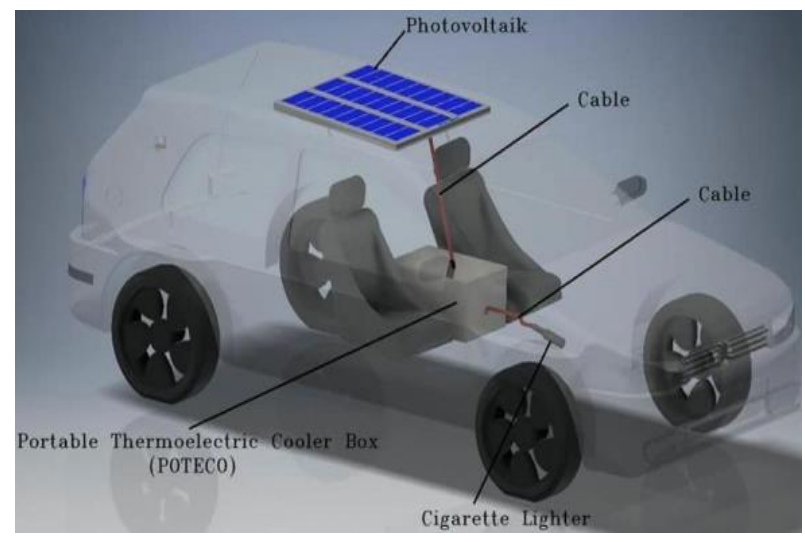

Figure 6. Work scheme of POTECO on vehicle
The results show that a temperature of $14.94^{\circ} \mathrm{C}$ is achieved in just 30 minutes, approximately 30 minutes faster than without fuzzy control. This number is also 13 hours faster than the time achieved by Aziz et al. [9] in the same TEC module, storage dimensions are almost the same as digital control methods. Furthermore, the POTECO storage if placed in the car cabin will look like in Figure 6 positioned between the driver and accompanying passengers in front.

\section{Conclusion}

In this experiment it was found that the fuzzy control design works well and is faster in reaching the cold side of the TEC temperature as early set-up. This possibility is caused by a source of DC electrical energy as the TEC input produces a large amount of power at $85 \mathrm{Wp}$. Further work is needed to assess the performance of cooling systems with variations in series and parallel TEC modules and the stability of the system for long periods of time. Furthermore, the cigarette lighter performance of the car needs to be tested as a DC power source.

\section{Acknowledgements}

Thank you to Aria Nurul Haq, a student of Electrical Engineering at Tadulako University who has contributed greatly to the experiment and design of its fuzzy control.

\section{References}

[1] N. Watjanatepin and P. Somboonkij, "The Design and Development of Photovoltaic Electrical Generating System Experimental Set," pp. 120-123, 2010.

[2] P. Li, L. Cai, P. Zhai, X. Tang, Q. Zhang, and M. Niino, "Design of a concentration solar thermoelectric generator," J. Electron. Mater. vol. 39, no. 9, pp. 1522-1530, 2010.

[3] G. Min, "Thermoelectric module design under a given thermal input: Theory and example," J. Electron. Mater., vol. 42, no. 7, pp. 22392242, 2013.

[4] P. Cheng, "The design of solar temperature difference power generation device," no. Isss, pp. 458-461, 2015.

[5] Mustofa, Basri, and Y. A. Rahman, "Experimental investigation from different focal length of Fresnel lens on thermoelectric generators performance," in IOP Conf. Series: Earth and Environmental Science 175 (2018) 012004, 2018.

[6] Mustofa, Z. Djafar, W. H. Piarah, and Syafaruddin, "A New Hybrid of Photovoltaic-thermoelectric Generator with Hot Mirror as Spectrum Splitter,” J. Phys. Sci., vol. 29, pp. 63-75, 2018.

[7] F. J. Willars-Rodriguez, E. A. Chavez-Urbiola, P. Vorobiev, and Y. V Vorobiev, "Investigation of solar hybrid system with concentrating Fresnel lens , photovoltaic and thermoelectric generators," Int. J. Energy Res., 2016.

[8] D. K. Chavhan and S. D. Mahajan, "Testing and Validation of Thermoelectric Coolers," Int. J. Eng. Res. Appl., vol. 5, no. 8, pp. 59, 2015.

[9] R. Aziz, M. Tanwirul, S. Sunanto, and K. Karsid, "Sistem Kontrol Suhu Penyimpan Buah-Sayur Pada Mesin Pendingin," J. Teknol. Terap., vol. 3, no. September, pp. 32-36, 2017.

[10] K. Teffah, Y. Zhang, and X. Mou, "Modeling and Experimentation of New Thermoelectric Cooler-Thermoelectric Generator Module," Energies, MDPI, vol. 1, no. 1, 2018.

[11] H. Najafi and K. A. Woodbury, "Optimization of a cooling system based on Peltier effect for photovoltaic cells," Sol. Energy, vol. 91, pp. 152-160, 2013.

[12] J. Jumiyatun and M. Mustofa, "Controlling DC-DC Buck Converter Using Fuzzy- PID with DC motor load," in IOP Conf. Series: Earth and Environmental Science 156 (2018) 012003, 2018. 
[13] G. Min and D. M. Rowe, "APPLIED thermoelectric domesticrefrigerators," vol. 83, pp. 133-152, 2006.
[14] G. Feng, "Introduction to Fuzzy Logic Control," Vol. 20102151, No. October, pp. 1-12, 2010. 